\title{
Optimizing Plant Density of Promising Rice Genotypes in Northwest Bangladesh
}

\author{
B Karmakar ${ }^{1 *}$, M A R Sarkar², M A Ali ${ }^{3}$ and S M Haefele ${ }^{4}$
}

\begin{abstract}
A study was conducted at the Bangladesh Rice Research Institute, regional station farm, Rajshahi, Bangladesh, during 2010 and 2011 wet seasons to determine the effect of plant density on the performance of different genotypes. Three plant densities $(20-\times 15-, 20-\times 20$ - and $25-\times 15-\mathrm{cm}$ spacing) and six genotypes (BRRI dhan56, BRRI dhan57, IR83377-B-B-93-3, IRRI 123, IR83381-B-B-6-1 and Binadhan-7) were tested in a strip-plot design with three replications, placing planting densities in the vertical plots and genotypes in the horizontal plots. Planting density $\times$ genotype produced significant effect on grain yield in 2011 but not in 2010. BRRI dhan56, BRRI dhan57 and IR83381-B-B-6-1 produced the highest grain yield in 20- $\times 15-\mathrm{cm}$ spacing, while the other genotypes (IR83377-B-B-93-3, IRRI 123 and Binadhan-7) produced the higher yields in 25- $\times 15-$ or 20- $\times 20$-cm spacing. In both years, genotypes had significant effects on grain yield, all yield components, growth duration, plant height, tillers hill- 1 and tillers $\mathrm{m}^{-2}$, but not on straw and biological yield. Among the genotypes, IR83377-B-B-93-3 gave the highest mean grain yield ( $\left.5.11 \mathrm{t} \mathrm{ha}^{-1}\right)$ followed by IRRI 123 $\left(4.97 \mathrm{tha}^{-1}\right)$. The lowest mean yield $\left(4.04 \mathrm{t} \mathrm{ha}^{-1}\right)$ was found in BRRI dhan57 followed by IR83381-B-B-6-1 (4.14 $\mathrm{t}$ ha-1 ${ }^{-1}$. Planting density had significant effects on grain yield, panicles hill-1, panicles $\mathrm{m}^{-2}$, tillers hill-1 ${ }^{-1}$ and tillers $\mathrm{m}^{-2}$, and closer spacing reduced the number of days to flowering and maturity. Short duration rice genotypes achieved higher grain yields in closer spacing while longer duration genotypes produced higher grain yields in wider spacing. Results of this investigation suggest that the optimal plant density is dependent on varietal characteristics, and that current fixed planting densities used in many rice cropping systems are probably not adequate.
\end{abstract}

Key words: Grain yield, harvest index, interaction effects, phenology, plant spacing

\section{INTRODUCTION}

Plant density in the crop stand is an important factor, playing a significant role on growth, development and rice yield (Miah et al., 1990). Each rice plant in the crop stand depends on temperature, solar radiation, moisture, aeration and soil fertility for growth and yield. In dense populations, the individual plant gets less resources whereas resources may be used less efficiently with a wide spacing. Optimum hill spacing ensures the optimum growth of above and below ground plant parts, making best use of available resources (Miah et al., 1990). Therefore, it is necessary to determine the optimum plant density per unit area to achieve highest yields (Baloch et al., 2002). Consequently, many researchers have reported on the importance of maintaining a critical level of rice plant populations to maximize grain yield. Thus, a range of planting densities have been evaluated for better yield of rice (Akita and Tanaka, 1992; Latif et al., 2005; Thakur et al., 2009). But the optimal plant density will also be affected by varietal characteristics making it is necessary to determine the optimal plant density for new and promising rice genotypes (Chowdhury et al., 1993). A related issue is uneven hill spacing which creates uneven competition among plants for light, water, and nutrients. As a result, plant growth can be uneven and reduce grain yield. Even hill spacing may also improve crop canopy aeration, enhance soil respiration and allow better weed control, thereby contribute to higher yields (Gautam et al., 2008). Plant density and uneven hill spacing also affects yield determining factors like panicles per unit area, spikelet sterility and 1000-grain weight. And according to Counce (1987) and Kenneth et al. (1996), panicles $\mathrm{m}^{-2}$ is the single most important yield attribute, contributing $89 \%$ of the yield variation.

Farmers of northwest Bangladesh, usually transplant rice seedlings randomly and little concerned about planting density or evenness of the hill spacing. This results in a variable planting density with a highly dense population in some places of a plot and low planting density in other areas. As a results, plants might compete heavily and be short of resources in the densely planted areas and not fully use available resources in areas with a low planting density. It was also observed that pest infestation (weeds, insects and diseases) was higher in plots with suboptimal or uneven spacing. Very dense and/or irregular planting hampers intercultural operations (especially weeding between the rows) and might increase competition among plants for nutrients, air, water and light. Consequently, plants may become weaker, thinner and have lower grain yields (Salahuddin et al., 2009). As a result, better crop management practices including optimized plant density and even plant stand should be a good and cheap management intervention to increase rice yields.

With this introduction it can be concluded that there is a need to optimize the planting geometry for promising new rice genotypes. Therefore, the present study was undertaken to investigate the effect of plant density on the performance of several promising rice genotypes, to determine optimum spacing to attain maximum yields, and to analyze possible interactions between germplasm and planting density.

\footnotetext{
'Senior Scientific Officer, Adaptive Research Division, BRRI, Gazipur, Bangladesh. ${ }^{2}$ Professor, Dept. of Agronomy, Bangladesh Agricultural University, Mymensingh. ${ }^{3}$ Director (Research), BRRI, Gazipur, Bangladesh. 4Australian Centre for Plant Functional Genomics, University of Adelaide, Australia. *Corresponding author's email: biswajitbrri@gmail.com
} 


\section{MATERIALS AND METHODS}

The experiment was conducted during the 2010 and 2011 wet seasons from June to November at the experimental farm $\left(24^{\circ} 22^{\prime} \mathrm{N}\right.$ latitude, $88^{\circ} 40^{\prime} \mathrm{E}$ longitude, $\left.21 \mathrm{masl}\right)$ of the Bangladesh Rice Research Institute, regional station Rajshahi. The experimental site is located in the High Gangetic River Floodplain agro-ecological zone (AEZ) 11, characterized by a slightly alkaline soil with a $\mathrm{pH}$ of 8.1 and a silty loam texture (BARC, 2012). Three plant densities, $\mathrm{T}_{1}=20-\times 15-\mathrm{cm}\left(33.3\right.$ hills $\mathrm{m}^{-2}$ or 333,000 hills ha $\left.^{-1}\right), \mathrm{T}_{2}=20-\times$ $20-\mathrm{cm}\left(25\right.$ hills $\mathrm{m}^{-2}$ or 250,000 hills ha-1) and T3 $=25-\times 15-\mathrm{cm}$ (26.7 hills $\mathrm{m}^{-2}$ or 266,667 hills ha-1), and six genotypes including V1=BRRI dhan56, V2=BRRI dhan57, V3=IR83377B-B-93-3， V4=IRRI 123， V5=IR83381-B-B-6-1 and V6=Binadhan-7 were investigated. The experiment was laid out in a strip-plot design with three replications, placing planting densities in the main plots (vertical plot) and genotypes in the sub plots (horizontal plot). Unit plot size was $12 \mathrm{~m}^{2}(3-\times 4-\mathrm{m})$. Seedbed management was done according to the traditional farm practice (BRRI, 2011). Land was prepared according to the common practice of wetland soil preparation with puddling. Twenty-three-day-old seedlings were transplanted at three seedlings hill-1 ${ }^{-1}$ on 28 July 2010 and 30 July 2011 respectively. Spacing was maintained as per treatments. Fertilizers containing N, P, K, $\mathrm{S}$ and $\mathrm{Zn}$ were applied at the rates of 82, 15, 38, 10.6 and 2.7 $\mathrm{kg} \mathrm{ha}^{-1}$ respectively, using urea, TSP, MOP, gypsum and zinc sulfate. The full amount of TSP, MOP, gypsum, zinc sulfate and $1 / 3$ urea were applied during the final land preparation, just before transplanting. The remaining urea was top dressed in two equal splits at 20 days after transplanting (DAT) (tillering stage) and 40 DAT (panicle initiation stage) synchronized with rainfall or wet soil conditions, because the experiment was conducted under rainfed conditions. The crop was protected from pest infestation according to standard farm management practices. Furadan10G was applied at panicle initiation stage of the crop to protect from stem borer infestation. From the center of each plot, $6 \mathrm{~m}^{2}$ area was harvested for determination of grain and straw yields when $85 \%$ of the grains appeared yellowish (IRRI, 2014). Grain yield was adjusted to $14 \%$ moisture content, and expressed in $\mathrm{t} \mathrm{ha}^{-1}$. Yield component data were collected following recommended procedures (IRRI, 1994). Data gathered in the experiment were statistically analyzed following procedures described by Gomez and Gomez (1984). Analysis of variance (ANOVA) was conducted using the statistical software CropStat7.2. Means were compared with the least significant difference (LSD) test.

\section{RESULTS AND DISCUSSION}

Planting density and genotypes produced significant interactions for panicles hill-1 in 2010, and for grain yield, panicles hill- ${ }^{-1}$, panicles $\mathrm{m}^{-2}$ and harvest index in 2011 (Tables 1 and 2). Plant densities had no significant effect on the number of grains panicle ${ }^{-1}$ in both testing seasons and no interaction effects were detected (Tables 1 and 2). Figure 1 shows clear and consistent trends in the interactions of plant densities and genotypes on grain yield. In both seasons, genotypes V1, V2 and V5 achieved increasing grain yields with increasing plant density. Especially at low densities, a small increase in density (from 20- $\times 20-$ to $25-\times 15-\mathrm{cm}$ spacing) increased grain yields tremendously. In contrast, the genotypes V3, V4 and V6 lost some grain yield with increasing planting density in both the seasons. Thus, the analysis of interactions between genotype and planting density separated two groups of genotypes reacting differently to increasing plant density (Fig. 1). Group 1 (V1, V2, V5) had an asymptotic yield response to increasing planting density whereas group 2 (V3, V4, V6) had the asymptotic yield response to lower plant density. Both the reactions were also described by Counce (1987). 
Bangladesh Rice J. 18(1\&2): 1-7, 2014

Table 1. Interaction effect of genotype and plant density on yield and yield components of rice genotypes during 2010 wet

\begin{tabular}{|c|c|c|c|c|c|c|c|c|}
\hline \multicolumn{2}{|l|}{ Interaction of } & \multirow{2}{*}{$\begin{array}{c}\text { Grain } \\
\text { yield } \\
\left(\mathrm{t} \mathrm{ha}^{-1}\right)\end{array}$} & \multirow{2}{*}{$\begin{array}{c}\text { Panicles } \\
\text { hill }^{-1} \\
\text { (no.) }\end{array}$} & \multirow{2}{*}{$\begin{array}{c}\text { Panicles } \\
\mathrm{m}^{-2} \\
(\text { no. })\end{array}$} & \multirow{2}{*}{$\begin{array}{l}\text { Grains } \\
\text { panicle } \\
\text { (no.) }\end{array}$} & \multirow{2}{*}{$\begin{array}{l}\text { Sterility } \\
(\%)\end{array}$} & \multirow{2}{*}{$\begin{array}{l}1000- \\
\text { grain } \\
\text { wt }(g)\end{array}$} & \multirow{2}{*}{$\begin{array}{c}\text { Harvest } \\
\text { index }\end{array}$} \\
\hline Genotype & Plant density $(\mathrm{cm})$ & & & & & & & \\
\hline \multirow[t]{3}{*}{ BRRI dhan56 } & $20 \times 15$ & 4.94 & 7.9 & 263 & 86 & 16.4 & 23.2 & 0.51 \\
\hline & $20 \times 20$ & 4.17 & 9.8 & 244 & 87 & 17.8 & 23.4 & 0.49 \\
\hline & $25 \times 15$ & 4.82 & 9.7 & 258 & 88 & 16.4 & 23.4 & 0.49 \\
\hline \multirow[t]{3}{*}{ BRRI dhan57 } & $20 \times 15$ & 4.28 & 9.4 & 314 & 69 & 21.2 & 20.0 & 0.48 \\
\hline & $20 \times 20$ & 3.91 & 11.4 & 285 & 70 & 22.2 & 19.8 & 0.46 \\
\hline & $25 \times 15$ & 4.17 & 11.3 & 301 & 72 & 20.9 & 19.9 & 0.47 \\
\hline \multirow[t]{3}{*}{ IR83377-B-B-93-3 } & $20 \times 15$ & 5.08 & 8.0 & 268 & 87 & 18.1 & 23.4 & 0.50 \\
\hline & $20 \times 20$ & 5.22 & 11.3 & 282 & 85 & 16.7 & 23.4 & 0.50 \\
\hline & $25 \times 15$ & 5.50 & 10.9 & 291 & 86 & 16.0 & 23.5 & 0.51 \\
\hline \multirow[t]{3}{*}{ IRRI123 } & $20 \times 15$ & 4.82 & 8.8 & 294 & 77 & 19.9 & 23.2 & 0.50 \\
\hline & $20 \times 20$ & 5.28 & 12.6 & 314 & 78 & 17.1 & 23.3 & 0.50 \\
\hline & $25 \times 15$ & 5.12 & 11.6 & 308 & 79 & 16.7 & 23.5 & 0.50 \\
\hline \multirow[t]{3}{*}{ IR83381-B-B-6-1 } & $20 \times 15$ & 4.42 & 7.8 & 258 & 77 & 20.1 & 23.5 & 0.48 \\
\hline & $20 \times 20$ & 3.78 & 9.4 & 234 & 78 & 22.0 & 23.6 & 0.44 \\
\hline & $25 \times 15$ & 4.21 & 9.3 & 248 & 79 & 20.8 & 23.4 & 0.47 \\
\hline \multirow[t]{3}{*}{ Binadhan-7 } & $20 \times 15$ & 4.56 & 8.3 & 276 & 77 & 19.4 & 23.3 & 0.48 \\
\hline & $20 \times 20$ & 5.00 & 12.2 & 306 & 76 & 16.7 & 23.5 & 0.50 \\
\hline & $25 \times 15$ & 5.18 & 11.7 & 311 & 78 & 16.4 & 23.4 & 0.50 \\
\hline \multicolumn{2}{|c|}{ LSD.05 for genotype $(\mathrm{G})$} & $0.57^{* *}$ & $0.7^{* *}$ & $20.3^{* *}$ & $3.2 * *$ & $3.2 *$ & 0.2 ** & $0.02 * *$ \\
\hline \multicolumn{2}{|c|}{$\mathrm{LSD}_{.05}$ for plant density $(\mathrm{S})$} & $0.18 *$ & $0.2 * *$ & 6.9 * & ns & ns & ns & ns \\
\hline \multicolumn{2}{|l|}{$\mathrm{LSD}_{.05}$ for $\mathrm{G} \times \mathrm{S}$} & ns & 1.0 * & ns & ns & ns & ns & ns \\
\hline \multicolumn{2}{|l|}{$\mathrm{CV}(\%)$ for $\mathrm{G}$} & 11.6 & 6.7 & 6.9 & 3.8 & 16.5 & 0.9 & 4.1 \\
\hline \multicolumn{2}{|l|}{ CV (\%) for S } & 4.1 & 2.4 & 2.7 & 0.5 & 3.2 & 0.5 & 1.9 \\
\hline \multicolumn{2}{|l|}{$C V(\%)$ for $G \times S$} & 10.8 & 5.9 & 5.7 & 1.1 & 2.1 & 3.0 & 2.8 \\
\hline
\end{tabular}

${ }^{*} \mathrm{P} \leq 0.05$ : significant, ${ }^{* *} \mathrm{P} \leq 0.01$ : highly significant and $\mathrm{ns}=$ not significant.

Table 2. Interaction effect of genotype and plant density on yield and yield components of rice genotypes during 2011 wet season.

\begin{tabular}{|c|c|c|c|c|c|c|c|c|}
\hline \multicolumn{2}{|l|}{ Interaction of } & \multirow{2}{*}{$\begin{array}{l}\text { Grain } \\
\text { yield } \\
\left(\mathrm{t} \mathrm{ha}^{-1}\right) \\
\end{array}$} & \multirow{2}{*}{$\begin{array}{c}\text { Panicles } \\
\text { hill }{ }^{-1} \\
\text { (no.) }\end{array}$} & \multirow{2}{*}{$\begin{array}{c}\text { Panicles } \\
\mathrm{m}^{-2} \\
\text { (no.) }\end{array}$} & \multirow{2}{*}{$\begin{array}{c}\text { Grains } \\
\text { panicle-1 } \\
\text { (no.) }\end{array}$} & \multirow{2}{*}{$\begin{array}{l}\text { Sterility } \\
(\%)\end{array}$} & \multirow{2}{*}{$\begin{array}{l}1000- \\
\text { grain } \\
\text { wt (g) }\end{array}$} & \multirow{2}{*}{$\begin{array}{c}\text { Harvest } \\
\text { index }\end{array}$} \\
\hline Genotype & Plant density $(\mathrm{cm})$ & & & & & & & \\
\hline \multirow[t]{3}{*}{ BRRI dhan56 } & $20 \times 15$ & 4.82 & 7.8 & 261 & 83 & 18.2 & 23.0 & 0.50 \\
\hline & $20 \times 20$ & 4.02 & 9.4 & 234 & 83 & 19.2 & 23.1 & 0.50 \\
\hline & $25 \times 15$ & 4.60 & 9.5 & 254 & 86 & 17.1 & 23.2 & 0.52 \\
\hline \multirow[t]{3}{*}{ BRRI dhan57 } & $20 \times 15$ & 4.34 & 9.5 & 316 & 70 & 22.2 & 19.7 & 0.48 \\
\hline & $20 \times 20$ & 3.41 & 11.0 & 274 & 73 & 23.0 & 20.0 & 0.44 \\
\hline & $25 \times 15$ & 4.10 & 10.6 & 282 & 75 & 21.2 & 20.1 & 0.46 \\
\hline \multirow[t]{3}{*}{ IR83377-B-B-93-3 } & $20 \times 15$ & 4.56 & 7.6 & 255 & 83 & 19.0 & 23.2 & 0.51 \\
\hline & $20 \times 20$ & 5.00 & 10.6 & 266 & 86 & 17.5 & 23.5 & 0.52 \\
\hline & $25 \times 15$ & 5.26 & 10.4 & 276 & 87 & 16.8 & 23.4 & 0.52 \\
\hline \multirow[t]{3}{*}{ IRRI123 } & $20 \times 15$ & 4.53 & 8.3 & 278 & 76 & 19.7 & 23.2 & 0.49 \\
\hline & $20 \times 20$ & 4.87 & 11.8 & 294 & 76 & 17.2 & 23.3 & 0.50 \\
\hline & $25 \times 15$ & 5.20 & 11.5 & 306 & 78 & 16.6 & 23.5 & 0.51 \\
\hline \multirow[t]{3}{*}{ IR83381-B-B-6-1 } & $20 \times 15$ & 4.51 & 7.9 & 264 & 75 & 22.1 & 23.5 & 0.48 \\
\hline & $20 \times 20$ & 3.61 & 9.4 & 234 & 75 & 24.4 & 23.4 & 0.44 \\
\hline & $25 \times 15$ & 4.26 & 9.6 & 256 & 79 & 22.2 & 23.6 & 0.47 \\
\hline \multirow[t]{3}{*}{ Binadhan-7 } & $20 \times 15$ & 4.35 & 8.0 & 266 & 76 & 19.6 & 23.4 & 0.48 \\
\hline & $20 \times 20$ & 5.01 & 11.6 & 291 & 78 & 18.7 & 23.3 & 0.50 \\
\hline & $25 \times 15$ & 4.91 & 10.7 & 284 & 80 & 17.3 & 23.3 & 0.51 \\
\hline \multicolumn{2}{|c|}{$\mathrm{LSD}_{.05}$ for genotype $(\mathrm{G})$} & $0.58 * *$ & $0.7^{* *}$ & $19.0 * *$ & 4.5 ** & 4.1 * & 0.4 ** & 0.01 ** \\
\hline \multicolumn{2}{|c|}{ LSD. $_{.05}$ for plant density $(S)$} & ns & 0.8 ** & ns & ns & ns & ns & $0.01 *$ \\
\hline \multicolumn{2}{|l|}{$\mathrm{LSD}_{.05}$ for $\mathrm{G} \times \mathrm{S}$} & $0.64 * *$ & $0.8 * *$ & $20.0 * *$ & ns & ns & ns & 0.02 ** \\
\hline \multicolumn{2}{|l|}{$\mathrm{CV}(\%)$ for $\mathrm{G}$} & 12.1 & 6.8 & 6.7 & 5.5 & 20.2 & 1.7 & 2.8 \\
\hline \multicolumn{2}{|l|}{ CV (\%) for S } & 15.4 & 8.9 & 8.3 & 7.5 & 24.3 & 1.4 & 2.5 \\
\hline \multicolumn{2}{|l|}{$C V(\%)$ for $G \times S$} & 8.3 & 4.6 & 4.3 & 2.9 & 12.8 & 1.5 & 2.7 \\
\hline
\end{tabular}

${ }^{*} \mathrm{P} \leq 0.05$ : significant, ${ }^{* *} \mathrm{P} \leq 0.01$ : highly significant and $\mathrm{ns}=$ not significant. 

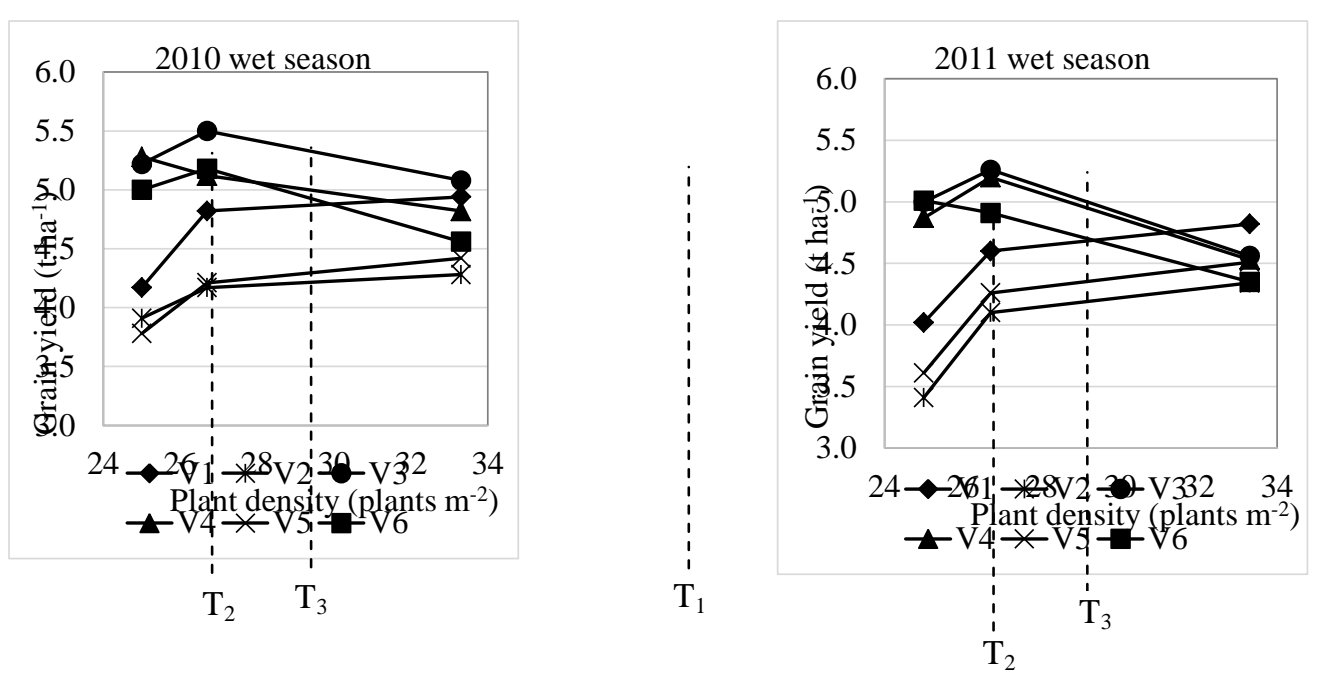

Fig. 1. Effect of genotype and plant density on grain yield for all rice genotypes (V1=BRRI dhan56, V2=BRRI dhan57, V3=IR83377-B-B-93-3, V4=IRRI123, V5=IR83381-B-B-6-1 and V6=Binadhan-7) tested during 2010 and 2011 wet season
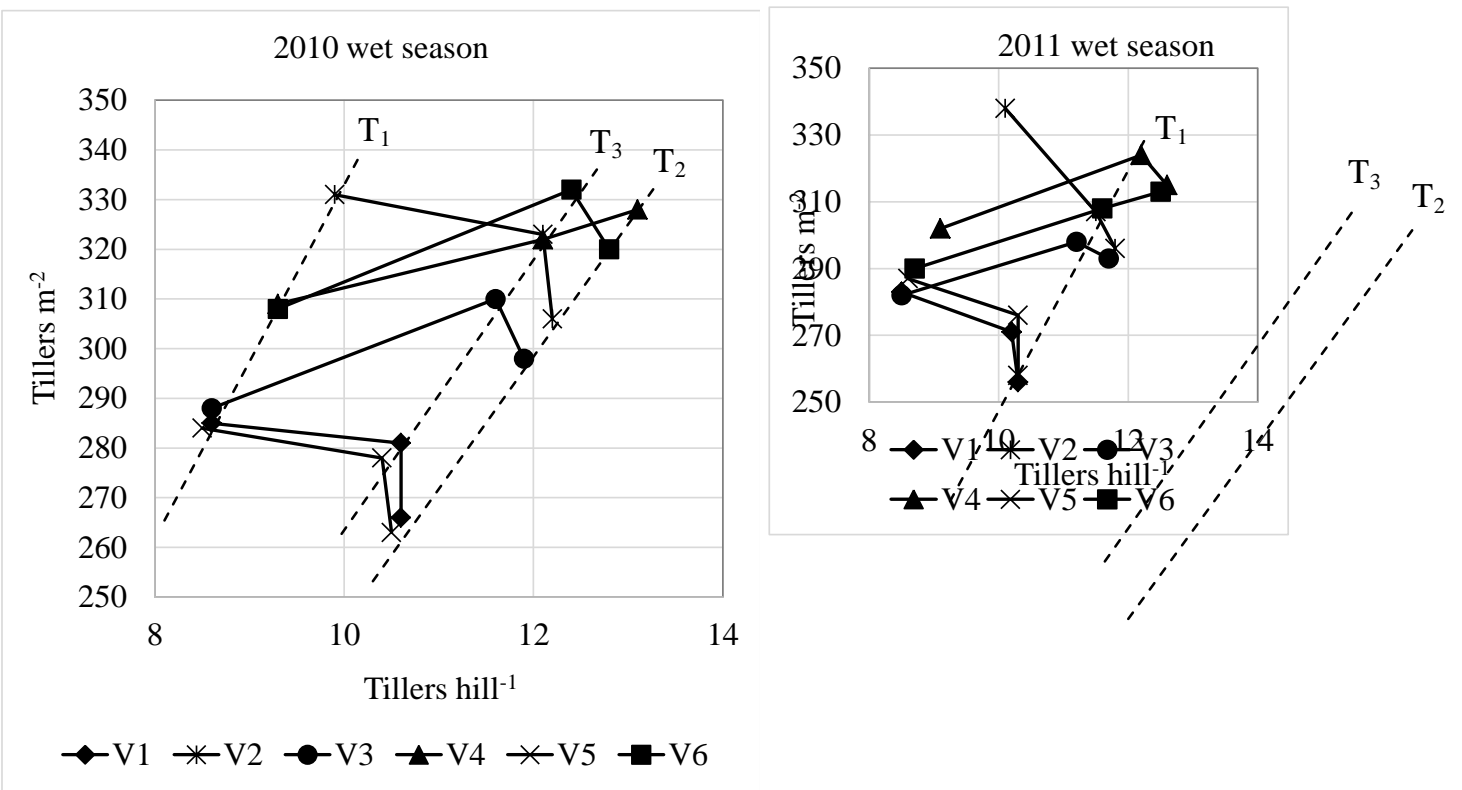

Fig. 2. Relation between tillers $\mathrm{m}^{-2}$ and tillers hill-1 for all genotypes (V1=BRRI dhan56, V2=BRRI dhan57, V3=IR83377-B-B-933, V4=IRRI123, V5=IR83381-B-B-6-1 and V6=Binadhan-7) and planting densities $\left(\mathrm{T}_{1}=20-\times 15-\mathrm{cm}\left(33.3 \mathrm{hills} \mathrm{m}^{-2}\right), \mathrm{T}_{2}=20-\times\right.$

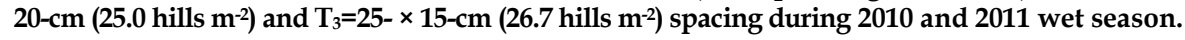

When comparing other characteristics of these two groups of genotypes, the only characteristics distinguishing them consistently were days to flowering, growth duration and straw yield (Tables 3 and 4 ). The group reacting positively to increasing plant density (V1, V2 and V5) was characterized by fewer days to flowering, shorter growth duration and lower straw yield. Thus, it can be hypothesized that lower biomass accumulation (which goes together with earliness) and less competition favours higher planting densities whereas genotypes with a higher biomass accumulation and longer duration perform better under lower planting densities. However, these characteristics may 4 Karmakar et at also change with site and season.

With respect to phenology and agronomic attributes, significant interactions were only observed for the number of tillers hill-1 and the number of tillers per $\mathrm{m}^{-2}$, and these effects were consistent in both the seasons (Tables 3 and 4). All other phenology and agronomic characteristics (days to flowering, growth duration, plant height, straw yield and biological yield) seemed to be affected by the plant density treatments in the same way in all genotypes (Tables 3 and 4), and therefore no significant interactions between density treatments and genotypes was detected. Figure 2 shows the graphical presentation of characteristics showing a significant interaction of genotype and plant density. As can 
be expected, the graph shows that with increasing planting density $\left(T_{2}<T_{3}<T_{1}\right)$ the number of tillers hill-1 decreases and the relation between tillers hill-1 and tillers $\mathrm{m}^{-2}$ is linear. But the graph also shows the two groups of genotypes identified in Figure 1 (V1, V2, V5 versus V3, V4, V6) react differently to the increasing plant density. The genotypes $\mathrm{V} 1, \mathrm{~V} 2$, V5 continue to increase the number of tillers $\mathrm{m}^{-2}$ with increasing planting density $\left(\mathrm{T}_{2}<\mathrm{T}_{3}<\mathrm{T}_{1}\right)$ whereas the number of tillers $\mathrm{m}^{-2}$ is decreasing from $T_{3}$ to $T_{1}$ for the genotypes V3, V4, V6. Thus, the yield decreases with the increasing planting density for these genotypes as shown in Figure 1 is directly related to a decreasing number of tillers $\mathrm{m}^{-2}$, probably caused, as indicated above, by a negative effect of too much biomass accumulation and competition between hills. This is the logic for most genotypes tested with respect to their number of tillers $\mathrm{m}^{-2}$ at low planting densities.
The genotypes V3, V4 and V6 have already high numbers of tillers $\mathrm{m}^{-2}$ at low planting densities, and a further increase in $T_{1}$ seems not possible. In contrast, the genotypes V1 and V5 have a low number of tillers $\mathrm{m}^{-2}$ at low plant densities and can obviously increase their tiller number $\mathrm{m}^{-2}$ with higher plant densities. The outlier seems to be genotype V2, which has many tillers $\mathrm{m}^{-2}$ at low planting densities but is able to further increase tiller number at higher planting densities. The low average yield of V2 despite the high number of tillers $\mathrm{m}^{-2}$ (Tables 1 and 2) can be explained by the combination of the lowest number of grains per panicle, a high sterility percentage and the lowest 1000-grain weight (Tables 1 and 2). And the tillers of V2 seem to have been relatively thin because the straw weight is also among the lowest of all genotypes tested although it had a high number of tillers $\mathrm{m}^{-2}$.

Table 3. Interaction effect of genotype and plant density on phenology and agronomic attributes of rice genotypes during

\begin{tabular}{|c|c|c|c|c|c|c|c|c|}
\hline \multicolumn{2}{|c|}{ Interaction of } & \multirow{2}{*}{$\begin{array}{c}\text { Flowering } \\
\text { (day) }\end{array}$} & \multirow{2}{*}{$\begin{array}{l}\text { Growth } \\
\text { duration } \\
\text { (day) }\end{array}$} & \multirow{2}{*}{$\begin{array}{l}\text { Plant ht } \\
(\mathrm{cm})\end{array}$} & \multirow{2}{*}{$\begin{array}{l}\text { Tillers } \\
\text { hill-1 }^{-1} \\
\text { (no.) }\end{array}$} & \multirow{2}{*}{$\begin{array}{c}\text { Tillers } \\
\mathrm{m}^{-2} \\
\text { (no.) }\end{array}$} & \multirow{2}{*}{$\begin{array}{c}\text { Straw } \\
\text { yield } \\
\left(\mathrm{t} \mathrm{ha}^{-1}\right)\end{array}$} & \multirow{2}{*}{$\begin{array}{l}\text { Biological } \\
\text { yield } \\
(\mathrm{t} \mathrm{ha-1})\end{array}$} \\
\hline Genotype & $\begin{array}{l}\text { Plant density } \\
(\mathrm{cm})\end{array}$ & & & & & & & \\
\hline \multirow[t]{3}{*}{ BRRI dhan56 } & $20 \times 15$ & 80 & 110 & 110 & 8.6 & 285 & 4.83 & 9.77 \\
\hline & $20 \times 20$ & 84 & 113 & 114 & 10.6 & 266 & 4.43 & 8.60 \\
\hline & $25 \times 15$ & 83 & 112 & 112 & 10.6 & 281 & 4.96 & 9.78 \\
\hline \multirow[t]{3}{*}{ BRRI dhan57 } & $20 \times 15$ & 77 & 105 & 102 & 9.9 & 331 & 4.67 & 8.95 \\
\hline & $20 \times 20$ & 80 & 108 & 99 & 12.2 & 306 & 4.62 & 8.53 \\
\hline & $25 \times 15$ & 79 & 107 & 101 & 12.1 & 323 & 4.81 & 8.98 \\
\hline \multirow[t]{3}{*}{ IR83377-B-B-93-3 } & $20 \times 15$ & 87 & 117 & 110 & 8.6 & 288 & 5.11 & 10.19 \\
\hline & $20 \times 20$ & 89 & 119 & 111 & 11.9 & 298 & 5.22 & 10.44 \\
\hline & $25 \times 15$ & 89 & 118 & 109 & 11.6 & 310 & 5.37 & 10.87 \\
\hline \multirow[t]{3}{*}{ IRRI123 } & $20 \times 15$ & 91 & 120 & 108 & 9.3 & 308 & 4.89 & 9.71 \\
\hline & $20 \times 20$ & 92 & 122 & 109 & 13.1 & 328 & 5.25 & 10.52 \\
\hline & $25 \times 15$ & 91 & 121 & 110 & 12.1 & 322 & 5.14 & 10.26 \\
\hline \multirow[t]{3}{*}{ IR83381-B-B-6-1 } & $20 \times 15$ & 85 & 114 & 111 & 8.5 & 284 & 4.88 & 9.30 \\
\hline & $20 \times 20$ & 86 & 116 & 112 & 10.5 & 263 & 4.72 & 8.50 \\
\hline & $25 \times 15$ & 85 & 114 & 111 & 10.4 & 278 & 4.82 & 9.03 \\
\hline \multirow[t]{3}{*}{ Binadhan-7 } & $20 \times 15$ & 87 & 117 & 100 & 9.3 & 308 & 4.88 & 9.44 \\
\hline & $20 \times 20$ & 89 & 119 & 102 & 12.8 & 320 & 5.01 & 10.01 \\
\hline & $25 \times 15$ & 88 & 117 & 101 & 12.4 & 332 & 5.28 & 10.46 \\
\hline \multicolumn{2}{|c|}{ LSD.05 for genotype (G) } & $1.0 * *$ & $1.2 * *$ & 2.1 ** & $0.6^{* *}$ & 17.0 ** & ns & ns \\
\hline \multicolumn{2}{|c|}{ LSD.05 for plant density (S) } & $1.0 * *$ & $0.8^{* *}$ & ns & $0.2^{* *}$ & 5.2 ** & ns & ns \\
\hline \multicolumn{2}{|c|}{$\mathrm{LSD}_{.05}$ for $\mathrm{G} \times \mathrm{S}$} & ns & ns & ns & 0.7 * & 20.4 * & ns & ns \\
\hline \multicolumn{2}{|l|}{ CV (\%) for G } & 1.2 & 1.0 & 1.9 & 5.3 & 5.4 & 14.6 & 12.7 \\
\hline \multicolumn{2}{|l|}{ CV (\%) forS } & 1.2 & 0.8 & 2.9 & 1.5 & 1.9 & 6.3 & 5.0 \\
\hline \multicolumn{2}{|l|}{$\mathrm{CV}(\%)$ for $\mathrm{G} \times \mathrm{S}$} & 1.4 & 1.0 & 2.2 & 4.0 & 4.0 & 11.9 & 11.1 \\
\hline
\end{tabular}

${ }^{*} \mathrm{P} \leq 0.05$ : significant, ${ }^{* *} \mathrm{P} \leq 0.01$ : highly significant and $\mathrm{ns}=$ not significant. 
Bangladesh Rice J. 18(1\&2): 1-7, 2014

Table 4. Interaction effect of genotype and plant density on phenology and agronomic attributes of rice genotypes during 2011 wet season

\begin{tabular}{|c|c|c|c|c|c|c|c|c|}
\hline \multicolumn{2}{|c|}{ Interaction of } & \multirow{2}{*}{$\begin{array}{c}\text { Flowering } \\
\text { (day) }\end{array}$} & \multirow{2}{*}{$\begin{array}{c}\text { Growth } \\
\text { duration } \\
\text { (day) }\end{array}$} & \multirow{2}{*}{$\begin{array}{l}\text { Plant } \\
\text { height } \\
(\mathrm{cm})\end{array}$} & \multirow{2}{*}{$\begin{array}{c}\text { Tillers } \\
\text { hill-1 }^{-1} \\
\text { (no.) }\end{array}$} & \multirow{2}{*}{$\begin{array}{c}\text { Tillers } \\
\mathrm{m}^{-2} \\
\text { (no.) }\end{array}$} & \multirow{2}{*}{$\begin{array}{c}\text { Straw } \\
\text { yield } \\
\left(\mathrm{t} \mathrm{ha}^{-1}\right)\end{array}$} & \multirow{2}{*}{$\begin{array}{c}\text { Biological } \\
\text { yield } \\
\left(\mathrm{t} \mathrm{ha} \mathrm{a}^{-1}\right)\end{array}$} \\
\hline Genotype & Plant density $(\mathrm{cm})$ & & & & & & & \\
\hline \multirow[t]{3}{*}{ BRRI dhan56 } & $20 \times 15$ & 81 & 110 & 111 & 8.5 & 283 & 4.86 & 9.69 \\
\hline & $20 \times 20$ & 82 & 111 & 113 & 10.3 & 256 & 4.00 & 8.02 \\
\hline & $25 \times 15$ & 81 & 110 & 110 & 10.2 & 271 & 4.23 & 8.84 \\
\hline \multirow[t]{3}{*}{ BRRI dhan57 } & $20 \times 15$ & 76 & 103 & 99 & 10.1 & 338 & 4.76 & 9.10 \\
\hline & $20 \times 20$ & 77 & 105 & 102 & 11.8 & 296 & 4.33 & 7.74 \\
\hline & $25 \times 15$ & 76 & 104 & 101 & 11.5 & 307 & 4.82 & 8.92 \\
\hline \multirow[t]{3}{*}{ IR83377-B-B-93-3 } & $20 \times 15$ & 86 & 116 & 108 & 8.5 & 282 & 4.41 & 8.97 \\
\hline & $20 \times 20$ & 88 & 118 & 111 & 11.7 & 293 & 4.58 & 9.59 \\
\hline & $25 \times 15$ & 87 & 117 & 110 & 11.2 & 298 & 4.90 & 10.16 \\
\hline \multirow[t]{3}{*}{ IRRI123 } & $20 \times 15$ & 89 & 119 & 106 & 9.1 & 302 & 4.81 & 9.34 \\
\hline & $20 \times 20$ & 91 & 121 & 108 & 12.6 & 315 & 4.95 & 9.83 \\
\hline & $25 \times 15$ & 90 & 120 & 107 & 12.2 & 324 & 4.94 & 10.14 \\
\hline \multirow[t]{3}{*}{ IR83381-B-B-6-1 } & $20 \times 15$ & 84 & 113 & 109 & 8.6 & 287 & 4.95 & 9.46 \\
\hline & $20 \times 20$ & 85 & 115 & 111 & 10.3 & 258 & 4.65 & 8.26 \\
\hline & $25 \times 15$ & 84 & 114 & 112 & 10.3 & 276 & 4.94 & 9.20 \\
\hline \multirow[t]{3}{*}{ Binadhan-7 } & $20 \times 15$ & 86 & 116 & 97 & 8.7 & 290 & 4.73 & 9.08 \\
\hline & $20 \times 20$ & 88 & 118 & 99 & 12.5 & 313 & 4.98 & 9.99 \\
\hline & $25 \times 15$ & 87 & 117 & 100 & 11.6 & 308 & 4.79 & 9.69 \\
\hline \multicolumn{2}{|c|}{$\mathrm{LSD}_{.05}$ for genotype $(\mathrm{G})$} & $0.9 * *$ & $1.0 * *$ & $5.3^{* *}$ & $0.7^{* *}$ & 18.9 ** & ns & ns \\
\hline \multicolumn{2}{|c|}{ LSD. $.05_{\text {for plant density }(S)}$} & 0.7 ** & 0.7 ** & ns & $0.9 * *$ & ns & ns & ns \\
\hline \multicolumn{2}{|c|}{$\mathrm{LSD}_{.05}$ for $\mathrm{G} \times \mathrm{S}$} & ns & ns & ns & $0.7^{* * *}$ & 19.0 ** & ns & ns \\
\hline \multicolumn{2}{|l|}{$\mathrm{CV}(\%)$ for $\mathrm{G}$} & 1.0 & 0.8 & 4.7 & 6.1 & 6.1 & 14.7 & 13.2 \\
\hline \multicolumn{2}{|l|}{ CV (\%) for S } & 1.0 & 1.0 & 4.9 & 8.9 & 8.3 & 12.8 & 14.0 \\
\hline \multicolumn{2}{|l|}{$\mathrm{CV}(\%)$ for $\mathrm{G} \times \mathrm{S}$} & 1.3 & 1.1 & 3.2 & 4.0 & 3.8 & 10.8 & 9.2 \\
\hline
\end{tabular}

${ }^{*} \mathrm{P} \leq 0.05$ : significant, ${ }^{* *} \mathrm{P} \leq 0.01$ : highly significant and $\mathrm{ns}=$ not significant

\section{CONCLUSIONS}

The genotypes BRRI dhan56, BRRI dhan57 and IR83381-B-B6-1 performed best when transplanted with a $20-\times 15-\mathrm{cm}$ spacing, while the genotypes IR83377-B-B-93-3, IRRI123 and Binadhan-7 gave the highest yield with a $25-\times 15-\mathrm{cm}$ spacing during wet season in northwest Bangladesh. This means that there was strong genotype $x$ management interactions, indicating that optimal plant density can be dependent on varietal characteristics. Our results suggest that current fixed planting densities used in many rice cropping systems are not adequate, and that need to be adjusted to genotype season and perhaps location.

\section{REFERENCES}

Akita, K and N Tanaka. 1992. Effect of planting density and planting patterns of young seedlings transplanting on the growth and yield of rice plants. Japan. J. Crops Sci. 61(1): 80-86.

Amin, M, M A Khan, E A Khan and M Ramzan. 2004. Effect of increased plant density and fertilizer dose on the yield of rice variety IR-6. J. of Res (Sci.). 15(1): 9-16.

Avasthe, R K, S Verma, A Kumar and H Rahman. 2012. Performance of rice (Oryza sativa) varieties at different spacing under system of rice intensification (SRI) in mid hill acid soils of Sikkim. Indian J. of Agron. 57(1): 32-37.

Baloch, A W, A M Soomro, M A Javed, M Ahmed, H R Bughio, M S Bughio and N N Mastoi. 2002. Optimum plant density for high yield in Rice Oryza Sativa L. Asian J. of Plant Sci. 1(1): 25-27.

BARC (Bangladesh Agricultural Research Council). 2012. Fertilizer Recommendation Guide. Bangladesh Agril. Res. Council. Farm gate, Dhaka. pp. 22.

Bozorgi, H R, A Faraji, R K Danesh, A Keshavarz, E Azarpour and F Tarighi. 2011. Effect of Plant Density on Yield and Yield Components of Rice. World Appl. Sci. J. 12 (11): 2053-2057.

BRRI (Bangladesh Rice Research Institute). 2011. Adhunik Dhaner Chash (Cultivation of Modern Rice), Gazipur. pp. 5-28.

Counce, P A. 1987. Asymptotic and parabolic yield and linear nutrient content responses to rice population density. Agron. J. 79: 864-869.

Chowdhury, M J U, A U Sarkar, M A R Sarkar and M A Kashem. 1993. Effect of variety and number of seedlings per hill on the yield and its components of late transplanted aman rice. Bangladesh J. Agril. Sci. 20(2): 311-316.

Gautam, A K, D Kumar, Y S Shivay and B N Mishra. 2008. Influence of Nitrogen Levels and Plant Spacing on Growth, Productivity and Quality of Two Inbred Varieties and a Hybrid of Aromatic Rice. Archives of Agron. and Soil Sci. 54 (5): 515-532.

Gomez, K A and A A Gomez. 1984. Statistical Procedures for Agricultural Research. John Wiley and Sons. Inc. New York. USA. pp. 97-423.

Hasanuzzaman, M, M L Rahman, T S Roy, J U Ahmed and A S M Zobaer. 2009. Plant characters, yield components of late transplanted Aman rice as affected by plant 


\section{Bangladesh Rice J. 18(1\&2): 1-7, 2014}

spacing and number of seedlings per hill. Advances in Biological Res. 3(5-6): 201-207.

Horie, T, T Shiraiwa, K Homma, K Katsura, Y Maeda and H Yoshida. 2005. Can yields of lowland rice resume the increases that they showed in the 1980s? Plant Production Sci. 8: 251-272.

IRRI (International Rice Research Institute). 1994. Soil and
Plant Sampling and Measurements. Part-2-Plant Sampling and Management (IN6-02). Intl. Rice Res. Inst. Los Banos, Philippines. pp. 3-24.

IRRI (International Rice Research Institute). 2014. Standard Evaluation System for Rice. Intl. Rice Res. Inst. Los Banos, Philippines. pp. 1-57. 